\title{
LA MUERTE NO EXISTE; VARIACIONES EN LOS RITUALES DE VELACIÓN Y CREMACIÓN FRENTE A LA INHUMACIÓN. TIPOLOGÍAS \\ ACTUALES DE TANATORIOS Y CAMPOSANTOS
}

\author{
DEATH DOES NOT EXIST; VARIATIONS IN VIGIL AND CREMATION \\ RITUALS AGAINST INHUMATION. CURRENT TYPOLOGIES \\ OF FUNERAL HOMES AND CEMETERIES
}

Pablo Jesús Lorite Cruz *

Recibido: 01/02/2021 - Aceptado: 28/04/2021

Doi: https://dx.doi.org/10.6018/rmu.466301

Publicado bajo licencia CC BY-SA

\begin{abstract}
Resumen
Este artículo compara los antiguos rituales funerarios de velación (celebrados en las casas) e inhumación (en los cementerios, con su ritual de costumbres, en los que la presentación del cadáver era muy importante) con los nuevos rituales de velación en los tanatorios (lugares pensados para que la muerte no exista y se camufle con la vida), la cremación y los nuevos depósitos para depositar las cenizas (árboles, lagos, columbarios escondidos en las ciudades, ceniceros comunales...) o deshacerse de ellas. En estos (mar, aire, praderas en los cementerios, circuitos de agua...) no se conserva la reliquia sino la memoria, intentando esconder la muerte y aceptando falsamente que ésta no existe.
\end{abstract}

\section{Palabras clave}

Cementerio, velaciones antiguas, tanatorios, incineración, cenizas, deposición de cenizas, patrimonio cultural.

\begin{abstract}
This article compares the old funeral rituals of vigil (celebrated at home) and burial in cemeteries (with a long ritual full of customs where the presentation of the corpse was very important) with the new funeral rituals celebrated in funeral homes (places designed so that death does not exist and is camouflaged with life), the cremation and new places to deposit the ashes (trees, lakes, columbariums hidden in cities, communal ashtrays...) or getting rid of these through a new way where the relic is not preserved (sea, air, meadows in cemeteries, water circuits...), but the memory; trying to hide death and falsely accepting that it does not exist.
\end{abstract}

\section{Key words}

Cemetery, old funeral rituals, funeral homes, cremation, burial of ashes, deposit of ashes, cultural heritage.

* Doctor en Historia del Arte. Email: pablochechu@gmail.com. 


\section{INTRODUCCIÓN}

Pulvis es et in pulverem reverteris: acuérdate que eres polvo y en polvo te has de convertir (Misal Romano, miércoles de ceniza). Estas son las palabras extraídas del Génesis $(3,19)$ tras la caída de Adán y Eva con las que el sacerdote católico impone la ceniza en forma de cruz en la frente de los fieles el miércoles de ceniza, signo con el que se inicia el período de Cuaresma. Y, efectivamente, el final del cuerpo de todo ser humano es convertirse en polvo, pero ¿cuándo se debe de dar este proceso, pasados siglos del óbito o en las horas inmediatas a éste?

Para un poderoso cardenal de la Edad Media o Moderna era evidente, cuanto más tarde mejor. Su suntuosa tumba debía ser un lugar de observación de la catedral o templo por él fundado, en donde descansara, y, sobre ésta, se colgaría del techo su capelo cardenalicio, hasta que se transformara en polvo (caso interesante de este ejemplo es la catedral metropolitana y primada de Toledo). Para un gran prelado la muerte existía y mediante la memoria tangible con obras, en muchas ocasiones ostentosas, debía de ser recordada, así como sus rimbombantes eucaristías a lo largo de los años, realizadas con los mejores ternos negros, bordados en oro o plata, que, para tal fin, hubiera realizado en vida.

Un abismo respecto a las velaciones y funerales actuales (sean o no católicos); desde el fallecimiento hasta la destrucción del cuerpo sólo pasan unas horas y la tipología de zonas en los cementerios para la deposición de las cenizas está desarrollando unos nuevos espacios totalmente contrarios al camposanto romántico, en donde las cenizas no se atesoran, sino que se devuelven a la naturaleza, quedando tan sólo una frágil memoria, carente de la reliquia del difunto. Éste se vuelve intangible e irrecuperable, su descanso eterno es tan abstracto, que en realidad es como si la muerte no existiera.

Muy lejos de este planteamiento quedan las costumbres altamente perceptibles de que el difunto descanse en un buen ataúd (bien cerrado y con la llave guardada por un familiar); en un panteón, en donde, a ser posible, simplemente sea depositado en una repisa, ni siquiera inhumado, como ocurre por ejemplo en la mayoría de los grandes panteones del cementerio de Prazeres en Lisboa, y en algún momento exhumado para poder contemplar su momia; posiblemente para que sus restos compartan lugar con un nuevo familiar.

Vamos a dividir este trabajo en dos partes. En la primera trataremos la tipología del tanatorio que palía la muerte, comparando con los complejos velatorios en el domicilio del finado que, al menos hasta la última década del 
siglo XX, fueron corrientes (al presente no se han perdido, pero ya se pueden catalogar como una rareza conservada en pueblos muy pequeños). La segunda parte, la vamos a dedicar a los nuevos lugares de esparcimiento de cenizas, creados en la tierra bendecida de los cementerios ${ }^{1} \mathrm{o}$ en otros nuevos espacios. Si bien, los camposantos municipales se crearon en su mayoría en el siglo XIX para clausurar las fosas comunes y los pequeños cementerios parroquiales intramuros de la ciudad, o incluso los de considerable tamaño como el de los Santos Inocentes de París por el problema de las miasmas (Schriewer \& Martínez Cavero, 2012, 11-12) -concretamente esta práctica fue prohibida en España por Carlos III en 1787 (Fischer, 2019: 20-21); en París aparece un edicto similar en 1763 (Schriewer \& Martínez Cavero, 2012: 12), en el reinado de Luis XV-. Ahora las criptas de las iglesias vuelven a ser lugar de enterramiento de cenizas, sobre todo en aquellas donde las cofradías y hermandades -en su mayoría de pasión o patronales- tienen mucho peso, caso señero de la ciudad de Málaga.

\section{TIPOLOGÍA DEL TANATORIO}

Siguiendo la costumbre española, se está construyendo cada vez con mayor desarrollo y complejidad un nuevo edificio de servicios denominado tanatorio, que suple dos costumbres: las velaciones en los domicilios (la casa mortuoria) y en los locales funerarios, que contaban con un único túmulo, un salón y que podían estar ubicados en cualquier lugar del núcleo. Esto suponía en muchas ocasiones una huida de la vecindad, sobre todo si la funeraria estaba en los bajos de un bloque de pisos, pues perdían un considerable valor de venta. Este problema conllevó en pocos años a la necesidad de tanatorios, incluso en poblaciones pequeñas. Existe una parodia española muy bufona de este problema en la serie Aqui no hay quien viva (2003), en ella los vecinos se encuentran con la inminente apertura de una de estas funerarias en su comunidad y las diversas peripecias para intentar deshacerse de tan incómodo negocio. $^{2}$

1 Existe un pontifical muy complejo y al presente prácticamente perdido por el cual el obispo bendecía mediante la instalación de una primera cruz el nuevo camposanto, sobre ésta se ponía 3 velas y el prelado la incensaba. Para una mayor ampliación del rito (Cfr. Aldobrandini, 1595, 455-474).

2 Capítulo 11 de la primera temporada, titulado Erase un traspaso. En el desarrollo de la parodia terminan robando un difunto para conseguir que la empresa cierre. 
La diferencia es profunda. En una muerte de mediados del siglo XX, en la que tenía mucha importancia la agonía modélica y el valor del moribundo de enfrentarse a ésta, pues se llamaba a un sacerdote a la casa para que le administrara los tres sacramentos esenciales para partir (Gómez, 2014: 15): la Penitencia, con la finalidad de que se marchara limpio de pecados; la Extremaunción, para que recibiera fuerza en el momento del último viaje, y la postrimera Eucaristía, para que se fuera en comunión con Dios. El principal de los sacramentos en la agonía era muy importante, incluso en la hagiografía de los santos hay milagros. Uno de los casos más curiosos es la repentina muerte de San Buenaventura en el II Concilio de Lyon; conllevó que el santo cardenal franciscano no comulgara, el Papa Gregorio X ante la presencia del rey de Aragón (Jaime I) decidió poner una hostia consagrada sobre el pecho del difunto y Ésta milagrosamente desapareció, entendiéndose que el santo teólogo había comulgado después de muerto; milagro famoso por ser representado por Zurbarán (Louvre).

Producido el óbito, lo primero que se hacía era llamar a la vecina valiente (normalmente mujer), que ayudaba a los dolientes más cercanos y que atesoraba el valor de amortajar al difunto. La mortaja normalmente había sido guardada por el fallecido por años y alguien cercano conocía cual era y el lugar en donde se encontraba el traje para el último viaje -normalmente negro y elegante, o el hábito penitencial de una cofradía- (Rodríguez, 2007: 144). Tomando como ejemplo el cine, al que queremos prestar atención en este trabajo, existe una parodia creada en 2019 por Frank Ariza en el largometraje ;Ay mi madre!, en donde la mortaja había sido demasiado bien guardada y, en su lugar, la conocedora encontró un vestido de gitana sevillana, entendiendo los presentes que la mujer deseaba ir vestida de fiesta. Esta idea en España está hoy prácticamente perdida -siendo el principal reducto conservador la etnia gitana-. Al presente, simplemente los funerarios introducen al difunto en un sudario, le realizan una pequeña tanatopraxia en el rostro (muy lejana a las ideas de embalsamar aceptadas en Estados Unidos) y se coloca la sábana de encaje. Por lo tanto, ni siquiera en muchas ocasiones se pueden ver las manos del difunto -normalmente con los dedos entrelazados o con la mano derecha sobre la izquierda-, perdiéndose la costumbre de adornarlas con una cruz o un rosario en el caso católico.

En la mentalidad actual de negar la muerte, cuanto menos haya que ver al difunto menos dolor causará. Es una idea y nuevo ritual, totalmente contrario a la necesidad que existía en décadas pasadas de certificar con la mirada de los visitantes en la velación que quien había sido anunciado como fallecido, verdaderamente estaba muerto. Algo que en el Barroco llegó a la cate- 
quesis plástica, pues, para entender en Semana Santa la resurrección de Cristo, era necesario sacar en procesión el Viernes o el Sábado Santo el cuerpo destrozado de Jesús; algo que no aparece en las escrituras, pero que era ineludible para que los fieles entendieran la muerte (Lorite, 2017: 854-857). Es más, el cuerpo se veneraba en una urna de cristal para adelantar la idea de resurrección, pues no se conserva con tanto lujo un cuerpo sobre el que se supone que no va a pasar nada (Lorite, 2011: 1-11). Está muy lejos el planteamiento de destrucción mediante la incineración. Es una imagen que se sale fuera de la religión católica, incluso llega a los cuentos, algo esperaban los siete enanitos que ocurriera en el cuerpo de Blancanieves para no destruirlo y conservarlo en una urna translucida de oro (Grimm, 2013: 279).

En los funerales antiguos, tras al acto de amortajamiento, se avisaba a la funeraria y ésta llevaba el arca; generalmente forrada de raso cárdeno como icono de los pecados del difunto (siguiendo la misma norma del color litúrgico morado que simbolizaba la penitencia). Sólo se forraban de raso blanco los ataúdes de los niños - por ser ángeles que iban directos al cielo- (Lorite, 2014: 229-246), las monjas -no existe el luto en una clausura- ${ }^{3}$ y las muchachas vírgenes. Muy clara deja esta idea Federico García Lorca en La casa de Bernarda Alba al engañar a todos, y que nadie se diera cuenta que su hija era una mal muerta por suicidio, lo que conllevaba la vergüenza y la pérdida de todo ritual religioso (Jordán \& Jordán, 2019: 153): «¡Descolgarla! ¡Mi hija ha muerto Virgen! Llevadla a su cuarto y vestirla como si fuera doncella. ¡Nadie dirá nada! ¡Ella ha muerto Virgen! Avisad que al amanecer den dos clamores las campanas. Y no quiero llantos. La muerte hay que mirarla cara a cara. ¡Silencio! ¡Nos hundiremos todas en un mar de luto! Ella, la hija menor de Bernarda Alba, ha muerto Virgen. ¡Silencio!» (García Lorca, ed. 1997, acto III). Del mismo modo los sepelios de las doncellas se llevaron al arte, caso por ejemplo del simbolista Julio Romero de Torres en jMira qué bonita era! (Museo Julio Romero de Torres de Córdoba).

El discurrir de los funerarios por las calles era un revuelo en la población y no estaba mal visto que se le preguntara a por quién iban, y estos gustosamente contestaban. Es más, el anuncio del óbito en muchas ocasiones no era con esquelas, sino con una especie de pregonero que iba avisando por las casas (casi llamando a los picaportes) como ocurría en Sepúlveda (Linaje, 2014, 148).

${ }^{3}$ La agonía de una religiosa de clausura es seguida por toda la comunidad, advirtiéndole la superiora a la moribunda que le ha llegado la hora y ésta le pide permiso para marchar. (Cf. Triviño, 2014, 676-677). 
La casa se adecentaba para el velorio y recibir a los acompañantes. Su distribución en el caserío tenía variantes, aunque la tipología era igual: una sala para el túmulo y otra en donde estaban los dolientes. Ésta se llenaba de sillas para todo el que llegara, aunque era el lugar principal para las mujeres, mientras que los hombres, la mayor parte del tiempo que duraba el velorio, estaban en la puerta de la casa. De tal modo que quien daba el pésame primero lo hacía a los hombres en el exterior, posteriormente a las mujeres en la sala y finalmente presentaba sus respetos al difunto. En realidad, este ritual ya era una modernización de otro más antiguo, en donde hombres y mujeres debían de estar en habitaciones separadas, sobre todo porque las mujeres se dedicaban a rezar y los hombres a conversar (Rodríguez, 2007: 138). Los rezos en las velaciones se han perdido, tanto los que podía dedicar cualquier fiel al presentarse ante el difunto, como los que se realizaban en comunidad durante la velación ${ }^{4}$ y los que efectuaban las mujeres cuando se llevaban el difunto a enterrar y ellas quedaban en la casa, que se completaban con un Santo Rosario y se repetían varios días. En general estas paraliturgias estaban dirigidas por una especialista a la que se le pagaba la voluntad por parte de los dolientes. Un reducto de estos rezos -en sus últimos momentos- lo incluye Antonio Mercero en Verano azul, cuando La Dorada se convierte en la casa mortuoria de Chanquete; en la escena en que Julia habla con Frasco en el exterior del barco se escuchan de fondo los rezos de las mujeres.

La distribución de cada casa condicionaba a dos tipologías. La más leve, era aquella por la que no era necesario observar al difunto, porque estaba en una habitación separada (normalmente un salón o un dormitorio); frente a la exposición de éste en el portal, lo que conllevaba sin remedio al paso por su lado para expresar la pena a los dolientes que están en la sala interior. Existen algunas variedades, por ejemplo, si se trataba de un hostelero, la velación se podía llevar a cabo en el restaurante.

El primer problema al que se enfrentaron las casas mortuorias fue la construcción de bloques de pisos con portales comunitarios. Los aparejadores a mediados del siglo XX no tuvieron en cuenta la confusión que podía con-

\footnotetext{
4 Se podían llevar a cabo por un sacerdote que visitara la casa mortuoria o por cualquier fiel que los conociera. Se resumían en una lectura de la I Carta de San Pablo a los Tesalonicenses y un evangelio que hablara de la resurrección. Después había unas preces dirigidas a los dolientes, al difunto y, finalmente, se recordaban los cuatro milagros de resurrección evangélicos: la del hijo de la viuda de Naín, la de la hija de Jairo, la de Lázaro y, por último, la de Cristo. Se invocaba a la Virgen, a San Pedro, a San Pablo, a San Juan, a San José y al santo por el que el difunto estuviera bautizado. Finalmente se rezaba un Padrenuestro y se pedía el descanso eterno (Pardo, 2007, 435-444).
} 
llevar el fallecimiento de un difunto, y los huecos de escalera eran tan estrechos que era imposible acceder con el féretro a un ático. Por pocas décadas la capilla ardiente se colocaba en el portal comunitario, sin que supusiera queja de ningún vecino, y la velación se celebraba en el piso del difunto, aunque los hombres solían quedar en la entrada del portal. En los bloques más ricos, que presentaban un hueco de escalera mayor, sí se acostumbraba a montar el túmulo dentro de la vivienda (con mucha frecuencia en los dormitorios), no obstante, en muchas ocasiones era compleja la bajada del féretro a la hora del entierro por las posiciones que éste debía de tomar.

La solución a todo esto fue el paso a la creación de funerarias en locales y, por el rechazo a éstas, se llegó a comenzar a definir la tipología del tanatorio. Por su forma éste se ha convertido en un lugar que ha ido evolucionando hasta llegar a construirse enormes complejos en las grandes ciudades, en donde se intenta a lo máximo paliar la muerte; convertir el servicio funerario en una despedida muy light, en la cual ni siquiera el difunto tenga que ir al cementerio porque haya sido respetuosamente destruido con anterioridad, mediante la cremación, en el mismo edificio utilizado para su sepelio.

Los tanatorios se acostumbran a ubicar en tres lugares. Los más raros, dentro del cementerio, formando una parte más de los complejos camposantos actuales, interesantes ejemplos tenemos en Ciriego (Santander) o la Fuensanta de Córdoba (tercero activo de la ciudad). Con posterioridad, junto al cementerio, formando un anexo al complejo funerario (el del camposanto de Málaga o el de San Fernando de Jaén) y, finalmente, en los polígonos industriales o periferias (el famoso de la M40 de Madrid es un claro ejemplo).

La diferencia esencial de un tanatorio es la vecindad de los difuntos y las familias; evidentemente siempre casuales, unidas en un mismo edificio por la muerte, cruzándose en los espacios públicos con la misma relación inexistente que en cualquier otro edificio de servicios. Gente que va y viene a expresar pesares; si bien en un edificio lleno de vida, de luz y en el que a pesar de haber muchos difuntos parece que no los hubiera. Si a esto añadimos la imaginación de muchos arquitectos, en realidad, en numerosas ocasiones el tanatorio se convierte en una obra de arte digna de contemplar en sus cuatro dimensiones; haciéndose algunos famosos, como el de León, realizado por Jordi Badía y Josep Val, que enterraron el edificio y sobre el techo crearon un estanque para el disfrute visual de las circundantes áreas residenciales (Amado, 2012: 294-296).

Lo primero que encontramos al penetrar en un tanatorio es un reconfortante hall con una recepción, confundible perfectamente con el de un hotel de lujo; espacio arquitectónicamente interesante, luminoso, con presencia de 
alguna fuente, plantas naturales, obras de arte... Abismal diferencia de la pequeña casa mortuoria en la que recibía el difunto. En contraste, simpáticos y educados recepcionistas uniformados nos ayudarán a buscar la velación en donde debemos de cumplir, además de estar perfectamente anunciado en las pantallas. Espaciosas escaleras, ascensores, aseos públicos, pasillos en los que veremos puertas numeradas y, sólo al traspasarlas, nos encontraremos con el sepelio, pero no con el difunto.

La tipología de cada sala de velación se ha desarrollado como un cómodo salón decorado con óleos, sofás, sillones reconfortantes, mesitas bajas y un número considerable de sillas. Efectivamente, la pena de los dolientes no se puede neutralizar, es lo único que hasta el presente no se ha conseguido cambiar, pero sí acortar los tiempos de irritación para los familiares, como de mejorar el mal rato para quienes tienen que cumplir.

La principal diferenciación en la tipología es que en todas las salas no existe la necesidad de observar al difunto, se da por hecho que otros han certificado su muerte. No obstante, éste es el protagonista y por tanto preside en su túmulo. Si bien, la localización de éste generalmente está en un ángulo de $90^{\circ}$, en el que su visión es imposible en toda la sala, salvo que nos pongamos delante del catafalco para observar directamente por un cristal, porque no es accesible. Sólo en esa ocasión todo aquel que no sea pobre de espiritu podrá cerciorarse de su presencia, siempre y cuando los familiares hayan decidido que el ataúd esté abierto, pues cada vez es más común que éste se muestre cerrado y adornado por una importante cantidad de flores. Es evidente que no causa la misma impresión en la observación directa de los familiares esta segunda posición del arca, impensable en décadas pasadas.

Ya no hay que llevar un tentempié a los afligidos, que se agradecía y casi que se obligaba a tomar, porque el dolor por la pérdida les había cerrado a todos las ganas de comer. En esencia, las atenciones se basaban en productos como el caldo, el café y la tila. En ese sentido los funerales españoles, al menos desde las primeras décadas del siglo XX hasta el presente, han sido muy estrictos. A lo sumo en las salas había agua y caramelos; idea que aún con poca fuerza, está cambiando con los servicios de catering, que agradecen a los presentes su visita y acompañamiento. Por el contrario, costumbre muy normal en otros lugares como Estados Unidos o Rusia, pero casi inexistente en España, desde que se perdió la tradición de los funerales de niños costeados por los abuelos, que había que festejar por su ascenso inmediato al cielo (Pérez, 2009: 43-47).

Aparece algo nuevo en los tanatorios, una cafetería; un espacio público impersonal, en donde poderse evadir en la visita al velorio, dejando la sala y tomando algo en una mesa o una barra, al lado de otras personas que de nada 
conocemos. Hay quien desayuna, quienes son invitados a un café por un doliente que necesita expansionarse, quienes incluso toman un menú a la hora del almuerzo o de la cena. Nada importa, no hay que esconderse, nadie va a criticar que ese nuevo servicio reste horas y camufle con vida al edificio de la muerte.

Es cierto que no es igual la funcionalidad de una cafetería en un tanatorio pequeño de unas seis salas (con un número inferior de salas la tipología es discutible y se parece más a un antiguo local funerario), frente al comportamiento de las grandes moles, preparadas para albergar muchos servicios al mismo tiempo. Podemos indicar que las de mayor tamaño en España son el tanatorio de Ronda de Dalt en Barcelona, con veinte salas, veintiuna tiene el de la M40 de Madrid, mismo número el de Cabueñes de Gijón, veintiocho el de Madrid Norte y veintinueve el de Parcemasa de Málaga (entre otros).

Dos empresas -con sus respectivos locales acotados- vamos a encontrar en estos edificios; las floristerías y los marmolistas. Mucho más importante la primera, porque los encargos no son sólo de los familiares sino de los amigos. El túmulo del difunto se decora con coronas de flores que simbolizan su triunfo (en recuerdo de las coronas católicas de los mártires o incluso de las coronas victoriosas grecorromanas), las palmas mortuorias (llenas del arte efímero de los floristas) y los ramos de flores. Respecto a los mármoles, permiten elegir en el mismo servicio la lápida para la tumba, nicho o columbario para los casos más conservadores, fieles a los cementerios que conocemos. Servicio inútil para las nuevas tipologías de camposantos, pensados con una diferente finalidad de deposición de las cenizas que veremos en la segunda parte de este trabajo.

Tanto por costumbre como por ley, un difunto debe de ser velado sobre unas 24 horas -basándose en los antiguos problemas de catalepsia-. Es posible que a los dolientes les haya llegado el acontecimiento de imprevisto y las peluquerías son importantes (sobre todo en las mujeres), muchos tanatorios ofrecen este servicio. No obstante, la estancia en el tanatorio no tiene por qué ser continuada frente a la costumbre en la casa mortuoria, que era durante toda la madrugada. En los edificios donde la muerte se transforma en vida hay descanso y las salas, en muchas ocasiones, cierran por la noche (a no ser de por la voluntad expresa de los familiares de querer velar).

Llegada la hora de la despedida, el tanatorio reduce e incluso suprime el principal ritual; la procesión, la sacramental, y así la debemos de llamar, pues, litúrgicamente hablando, dentro del catolicismo tenía una misma naturaleza que una procesión de Semana Santa. Todo empezaba cuando las campanas de la parroquia cercana comenzaban a doblar. Existía un toque especial que indi- 
caba la salida del sacerdote (Barroso, Alcalá \& Barroso, 2017, 300); al poco tiempo por la calle se veían aparecer a tres monaguillos con túnica negra -roja si era domingo- y sobrepelliz, portando la cruz parroquial con manga negra flanqueada por los 2 ciriales y el acetre con el hisopo; detrás el sacerdote con capa pluvial negra (Alcalá, 1992: 27) -perfectamente representado por Courbert en su Entierro de Ornans (Orsay)-. Dependiendo de la grandeza del entierro, el difunto podía ser llevado a hombros o en la carroza fúnebre, algunas muy artísticas -ejemplo es la importante colección del cementerio de Montjuic de Barcelona-, desde aquí el difunto podía ser trasladado a la iglesia -a la que entraba «con los pies por delante»- seguido de los familiares, que se colocaban en el primer banco; mientras el templo ya estaba abarrotado por los amigos. En la parroquia podía haber un oficio o directamente el difunto era conducido al cementerio (dependía de la costumbre de cada población). De haber oficio en la iglesia, se utilizaba la casulla negra, salvo que el finado fuera un niño o una virgen que, por su pureza, no tenían pecado y se oficiaba con una casulla blanca sin bordar, a diferencia de las valiosas casullas blancas que, según bordados, indican para qué día grande del catolicismo se utilizan.

La variabilidad es enorme, por ejemplo en dos ciudades tan cercanas como Úbeda y Baeza la costumbre era distinta. Mientras en Úbeda, terminado el oficio, el difunto se dejaba un tiempo a los pies del presbiterio mayor para que los fieles pasaran en fila para expresar su pesar a los dolientes que estaban en el primer banco; en Baeza, el finado quedaba en la carroza y los dolientes se ponían delante por dos veces para recibir el pésame, antes de introducir el cadáver en el templo y después de sacarlo y conducirlo al camposanto. Si se le acompañaba en el sentimiento por dos veces y, además, se le había hecho en la velación, mejor se quedaba con ellos.

Todas estas costumbres, llenas de rituales en donde la muerte existe, se diluyen en el oficio del tanatorio. Este tiene una capilla católica con una tipología ritual de Novus Ordo Romano que simplifica el presbiterio a un altar, un atril, una sede y un sagrario, que presiden un diáfano espacio asambleario y acogedor (por ejemplo, se suprime el cirio pascual de la collación). Estas capillas, pueden ser más o menos artísticas, dependiendo de cada caso, si bien racionalistas y prácticas.

Toda sacramental se diluye; simplemente una cortina tapará el cristal del túmulo y unos auxiliares de eventos invitarán al público a ir a la capilla; en donde por una puerta cercana al presbiterio aparecerá el féretro, el cual ha sido desplazado por pasillos internos que comunican todas las salas. Llegará el sacerdote, normalmente el párroco de la collación a la que pertenecía el finado. Gran diferencia, si antes los féretros iban a la parroquia y se movían 

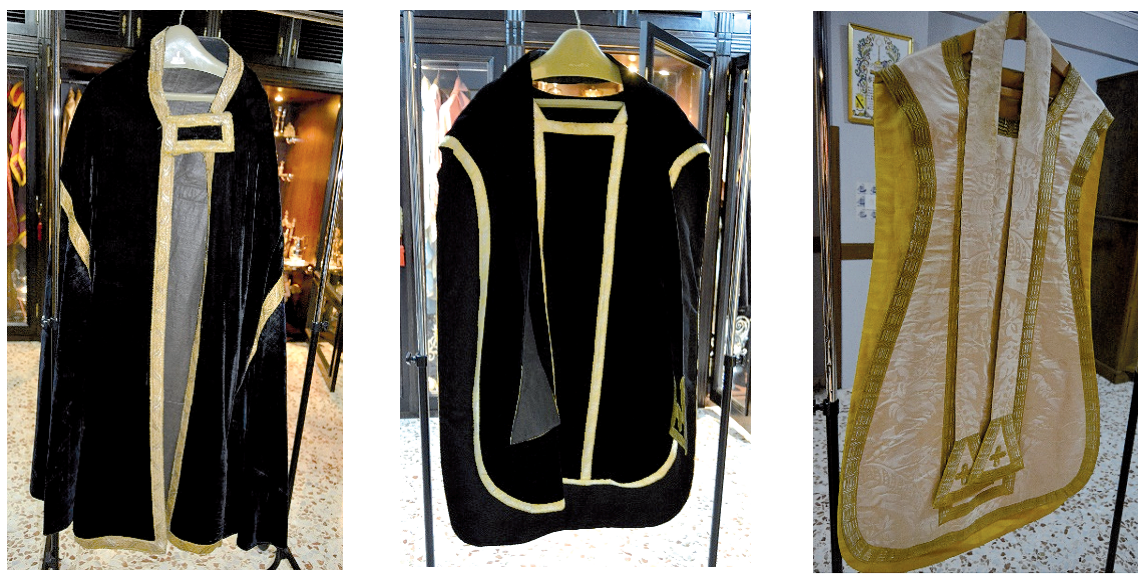

Figuras 1, 2 y 3. Ternos conservados en las cajoneras de la sacristía de la parroquia de la Asunción de Jódar. Fuente: propia.

1. Capa pluvial negra de terciopelo de finales del siglo XIX para los entierros.

2. Casulla negra de corte hispánico compañera del terno anterior para los oficios eucarísticos fúnebres.

3. Casulla blanca sin bordar de corte hispánico de principios del siglo XX para los funerales de niños.

por la población, ahora por los núcleos poblacionales ya no se ven difuntos. En cambio, son los presbíteros los que comparten las capillas de los tanatorios y su pequeña sacristía, así como sus ternos, que se reducen a una casulla morada de corte Novus Ordo, por si ofician la Eucaristía, y a una estola del mismo color si simplemente se ciñen a la liturgia de la palabra y al responso que puede ser perfectamente dirigida por un diácono a falta de presbíteros. En tanatorios de gran tamaño ni siquiera existe presencia de párrocos, sino la asignación de un capellán específico para todos los oficios por parte del obispado.

Para los funerales no religiosos el tanatorio tiene una sala ecuménica. Es una tipología parecida a la de un salón de actos, con la diferencia de que los fieles se sientan en sillas (en una capilla religiosa en bancos, porque estos tienen reclinatorios para la adoración al Santísimo Sacramento en el momento de la consagración), un atril junto al lugar en donde se coloca el féretro y multitud de actos con diversas palabras de despedida, música e ideas imaginativas, ya que no existen rituales estandarizados. En el fondo, una despedida lo más emotiva posible intentando agradar al difunto. 


\section{LOS NUEVOS CREMATORIOS}

Las estancias más llamativas de un tanatorio actual son las del crematorio. Con la finalidad de entender su ubicación y las dos tipologías actuales debemos de partir de la idea de que los primeros hornos no estaban en estos edificios, sino que eran una nueva tipología arquitectónica de los camposantos. Se acepta el año 1876 como el de la primera incineración moderna en Europa, concretamente en el cementerio de Milán; siendo el primer difunto un banquero suizo protestante llamado Alberto Keller (Marra, 2016: 34-35). Éste había mandado construir el templo crematorio para la ciudad. Pese a su novedad, una cremación no dejaba de ser una sacramental hasta el cementerio, en el cual, en vez de una inhumación, se veía la introducción del ataúd en un horno tras unas enormes puertas monumentales -no había intimidad familiar- $y$, tras el proceso, las cenizas eran enterradas en el mismo columbario del templo neoclásico. No existía una idea de tapar la muerte, pues las pompas fúnebres eran ostentosas y las tumbas permanentes. El propio Keller construyó un monumental panteón para sus cenizas, por lo que tenía muy claro la conservación de su memoria -influencia de los mausoleos de los emperadores romanos-.

Es una concepción muy diferente al tanatorio actual, en donde no es necesario que el difunto $y$, mucho más importante, los familiares, pisen el cementerio. Tras el servicio religioso o ecuménico, normalmente por los mismos pasillos interiores que anteriormente nombrábamos, el difunto termina en la sala de cremación y, si los familiares quieren; en un grupo muy reducido, desde una pequeña sala de agradable decoración y parecida a una sala de espera, por un cristal pueden observar la introducción del féretro o incluso accionar el mecanismo que inicie el proceso. Aun así, es costumbre efímera que se está empezando a perder. ¿Qué necesidad existe de contemplar momento tan desagradable? Mejor, terminado el servicio, despedir al difunto en la capilla o sala ecuménica y marcharse, incluso los dolientes. En horas desconocidas habrá quienes se encarguen de la incineración y, terminada, llamarán a otra sala cómoda en decoración para recoger las cenizas archivadas por horas o días en el mueble columbario que tiene el tanatorio. Totalmente perdidas quedan las costumbres de la antigüedad donde el momento de la cremación del difunto era el culmen, pensemos tan sólo como Suetonio indica que en la de Julio César, los legionarios lanzaron sus armas y las mujeres sus joyas a la pira, además de ser veladas las cenizas durante muchas noches (Suetonio, 51).

Por esta suplencia no se observa nada de la cremación, lo que conlleva a la creación de una nueva tipología en la que la sala de despedida se vuelve tea- 
tral, utilizándose la sala ecuménica llena de asientos. En ella, el arca se coloca en el centro y éste empieza a bajar a un piso inferior como si se tratara de una inhumación; acompañado el momento, por ejemplo, de la interpretación de una pieza musical que le gustara al difunto. Uno de los ejemplos más llamativos en España con esta disposición es la pirámide -recordando al mundo funerario egipcio- multiconfesional del crematorio de Montjuic (espacio utilizado en el cine por Albert Espinosa para la incineración de Benito en Pulseras Rojas, 2a temporada, capítulo 6).

La concepción de la utilización de un tanatorio ha adquirido tal peso que existen empresas que, para dar servicios en poblaciones muy pequeñas, en donde no se quiere que el recuerdo de la velación quede en la casa; están diseñando tanatorios móviles dentro de un camión, que llegan al núcleo del finado y se instalan por las horas que dura el sepelio. Evidentemente en este caso no existe la cremación, pero niega el halo del áspero recuerdo.

Pasadas unas horas o incluso unos días, los familiares reciben una urna con las cenizas. Sólo polvo verán si la desean abrir, pues los restos óseos calcinados han sido cremulados. Posiblemente dentro de unos años las cenizas sean níveas si se acepta la resomación ${ }^{5}$ o una especie de compost de forma compacta con la promación. ${ }^{6}$ Ya no existe el difunto, sino una materia abstracta del mismo. En cierto modo una reliquia simbólica que nos lleva a nuevos rituales y tipologías de cementerios, en donde mantenerlas de forma tangible, o devolverlas a la naturaleza para que jamás sean recuperadas $y$, en vez de un vestigio impreciso -si bien aceptado-, quede tan solo la memoria de lo que se ha devuelto a la madre tierra o se ha disuelto para unirse al ciclo hidrológico natural. Seguidamente vamos a desarrollar estos temas como segunda parte del trabajo.

\section{TIPOLOGÍA DE LOS NUEVOS CAMPOSANTOS PARA LAS CENIZAS}

En la doctrina católica no está clara la incineración; de hecho, en 1886 fue prohibida (Fischer, 2019: 26) por León XIII,7 en el sentido de la necesidad de conservar el cuerpo para la resurrección en el fin de los días. Si bien

\footnotetext{
5 Se trata de una técnica de destrucción del cadáver mediante disolución en un baño químico caliente. De manera científica se conoce como hidrólisis alcalina.

6 Es una técnica por la cual el cadáver se congela con nitrógeno líquido y, tras volverse quebradizo, con una vibración se convierte en pequeñas partículas que, perdida la humedad, son similares a las cenizas.

7 En el siglo Vincenzo Luigi Pecci. Sumo Pontífice Romano desde 1878 hasta 1903.
} 
hay un abismo entre las resurrecciones milagrosas que conllevan a una segunda muerte, caso de la de Lázaro (Jn 11, 144) frente a la resurrección eterna, en donde el cuerpo glorioso no es igual que el cuerpo mortal. Algo en lo que inciden mucho los evangelios cuando María Magdalena confunde a Jesús con un hortelano (Jn 20,14-17), los discípulos de Emaús no le conocen hasta que no bendice el pan (Lc 24, 13-35), o los propios apóstoles lo reconocen, pero no se atreven a preguntarle si es Él $(\mathrm{Jn} 21,12)$. Dentro de la modernidad que significó el pontificado de Pablo VI, ${ }^{8}$ en 1964 se acepta la cremación (Fischer, 2019: 26); si bien, muchos nuevos rituales en los que se pierden las reliquias del difunto son considerados irrespetuosos y, en 2016, pontificado de Francisco, ${ }^{9}$ se indica que las cenizas deben de descansar en lugar sagrado. Este cambio de pensamiento conlleva a un nuevo planteamiento de los cementerios, que evidentemente, comienzan de nuevo a ganar población; como a la mayor creación de columbarios en las criptas de los templos, tipología a la que nos referiremos con posterioridad.

Siguiendo esta idea, el Ritual de Exequias, en su capítulo Celebración de las exequias ante la urna de las cenizas, no varía demasiado de las exequias ante el cuerpo del difunto; de hecho, la urna se asperge -en recuerdo al sacramento del Bautismo-e inciensa. Es llamativo que denomina a las cenizas como «la última presencia sensible que de él (ella) tenemos». Posteriormente indican que esas cenizas resucitarán y las trata como un ser en varias ocasiones durante la despedida: «Lo que ahora sólo son sus cenizas fueron el templo del Espíritu y están llamadas a ser, por la Resurrección, piedras vivas del templo de la Jerusalén celestial». Seguidamente, siempre se va a referir a las cenizas como el cuerpo: "Que el Espíritu de Dios, con cuyo fuego ardiente fuiste madurado, revista tu cuerpo de inmortalidad». Al final recuerda a los presentes: «y a todos nosotros nos dé la certeza de que no está muerto, sino que duerme, de que no ha perdido la vida, sino que reposa, porque ha sido llamado a la vida eterna por los siglos de los siglos» (Ritual de exequias, 2018, s/p).

La primera opción de pérdida absoluta de la última reliquia es el esparcimiento de cenizas al viento, perdiendo hasta la forma definida del polvo unificado. Es una acción que rompe con cualquier idea de camposanto, así como la posibilidad de dejar siquiera una memoria escrita (en este sentido, una inexistencia total de la muerte, llegados a estos rituales generalmente poco tipificados y llenos de espontaneidad por los presentes). Es más, sólo es

\footnotetext{
8 En el siglo Juan Bautista Montini. Sumo Pontífice Romano desde 1967 hasta 1978.

9 En el siglo Jorge Mario Bergoglio. Sumo Pontífice Romano desde 2013 hasta el presente.
} 
un espacio mental en donde, por algún tiempo, quienes conservan en la memoria al difunto podrán ir, pero nada más. Las generaciones venideras no tendrán tangibilidad a ese ancestro.

Muchas veces son los medios de comunicación los que han normalizado estas nuevas formas, incluso los dibujos animados nos han mostrado esta práctica. Tan solo tenemos que pensar en Los Simpson, fallecida la madre de Homer, deja en una grabación el momento en que desde una montaña deben de lanzar sus cenizas, para que éstas se infiltren y hagan fallar el lanzamiento de un misil; recordando que se trataba de una activista del movimiento hippie. Curiosamente las cenizas son devueltas a su hijo en una bolsa de filtro que nuevamente las esparce a la nada.

Otro caso lo tenemos en la serie Cuéntame cómo pasó (temporada 16, capítulo 180), cuando de repente, en 1983, momento en que la incineración aún era extraña en España; Antonio Alcántara recibe por sorpresa en su piso las cenizas de su amigo Desiderio Quijo. Al verlas, la abuela Herminia se escandaliza porque considera que no va a tener un entierro digno; Nieves las confunde con un adorno que les ha regalado Desi y, una vez descubierto lo que era, pregunta si le han llegado por correo. Peor es la traviesa María Alcántara, que se las lleva para mostrarle a los niños que en su casa tiene un difunto. Accidentalmente se las deja a su amiga Gala, que deja la urna en una papelera. A pesar de estos puntos cómicos del capítulo -unidos a la personalidad del personaje de Desiderio- es una entrega trágica, que termina con las cenizas esparcidas desde la azotea de los pisos hacia todo el barrio ficticio madrileño de San Genaro.

Muy similar es el esparcimiento en el mar, río o laguna. Con una peculiaridad, la ceremonia es algo más fastuosa, ya que junto a las cenizas se pueden arrojar flores e incluso coronas completas. No es extraño en costas españolas, en donde la costumbre está generalizada, que pasados unos días en las playas puedan aparecer restos de estos rituales; o globos funerarios que son soltados al cielo como una oración tras esparcir las cenizas. En sus inicios fue una idea afín a los políticos e intelectuales de izquierdas, por ejemplo, las cenizas de Santiago Carrillo fueron lanzadas al mar Cantábrico desde Gijón, y las de Rafael Alberti al Mediterráneo desde el Puerto de Santa María.

Sí es cierto que esta concepción de izquierdas es occidental. En el mundo oriental, donde la incineración es común en muchísimas culturas, nos encontramos con que los jefes de estado revolucionarios de izquierdas han sido embalsamados en su mayoría, casos de Mao Tse Tun en China (fallecido en 1976), Kim Il-sung y Kim Jong-il en Corea del Norte (fallecidos en 1994 y 2001, ambos se veneran en el palacio del Sol de Kumsusan) y Ho Chi Minh 
en Vietnam (fallecido en 1969); mismo ejemplo tanto de Lenin como de Stalin en la desaparecida URSS (fallecidos en 1924 y 1953).

El caso en televisión más mediático de la práctica de esparcimiento de cenizas en un lago fue en la serie Médico de familia. El público quedó consternado en 1999 por la muerte inesperada y trágica de Marcial en el penúltimo capítulo. En el último, su pareja -Eva- confiesa que no puede tener las cenizas en casa y, en la cafetería, se las deja a Poli, el señor Manolo y el señor Matías; quienes discuten muchas de las formas de esparcimiento que estamos exponiendo, a la que añaden subirse a un globo aerostático y tirarlas desde el cielo. Finalmente, los tres, junto a la Juani; deciden ir a un lago privado, en donde los invitan a marcharse por no ser socios, roban una barca y, en el momento de lanzar las cenizas, indican que sentían que Marcial les fuera a gastar una de sus bromas pesadas, seguidamente se dan cuenta que se han quedado sin remos.

Los lagos están empezando a aparecer en los cementerios. Son es una nueva tipología, espaciosa, vistosa, con vida, pues siempre un lago, aunque sea artificial, puede albergar peces y atrae anfibios, bellos insectos como las libélulas y aves. En este sentido, se crea un espacio de vida mucho más allá de los típicos gatos que viven en muchos cementerios románticos para eliminar la población de roedores, que podían crear desperfectos en las tumbas; al mismo tiempo de la lógica prohibición de la entrada de perros por su gusto por los huesos. Casos de lagos de importante tamaño los encontramos por ejemplo en el cementerio mancomunado de la bahía de Cádiz o en el cementerio jardín de Alcalá de Henares. No obstante, en la mayoría de estos lagos no se permiten arrojar cenizas, sí enterrarlas alrededor, cuestión que veremos más adelante con la inhumación anónima.

Lo más común y estandarizado es que la urna con las cenizas se deposite en un columbario clásico en el camposanto, que responden a la misma estructura que ya utilizaran los romanos y sólo difieren de los nichos en su tamaño. Individualizados, no dejan de ser construcciones arquitectónicas en propiedad para una o varias urnas, en las que precisamente no se busca el anonimato, sino la memoria y, por tanto, la decoración con la lápida y el culto a la remembranza con las flores. En un columbario tradicional la muerte sí existe; simplemente se ha producido la cremación por el miedo a la putrefacción natural, acelerando el proceso, pero se quiere mantener el recuerdo con la reliquia. Como expresa Mónica Martínez, no dejan de ser «estanterías perpetuas» que se han ido añadiendo en los espacios residuales de los cementerios (Martínez, 2019, 97). Un ejemplo claro es el patio del siglo XIX del cementerio de San Ginés de la Jara de Úbeda. Derrumbado por causa de abandono el testero que ocupa- 
ban las antiguas dependencias de la sala de autopsias y depósito de cadáveres, se ha construido en el mismo lugar el único testero de columbarios que existe en dicha necrópolis.

En el fondo, en esta clase de columbarios existe la misma idea de inviolabilidad a lo sacro; profanar las cenizas de un columbario es lo mismo que alterar el descanso eterno al exhumar impunemente a un difunto de su tumba por alguna idea diferente al traslado consensuado en su mejora (robarle, mofarse del mismo por sus acciones en vida, vengarse en sus restos por lo que hizo en su pasado...). Estas acciones se consideran sacrilegio dentro del catolicismo, al punto de ser

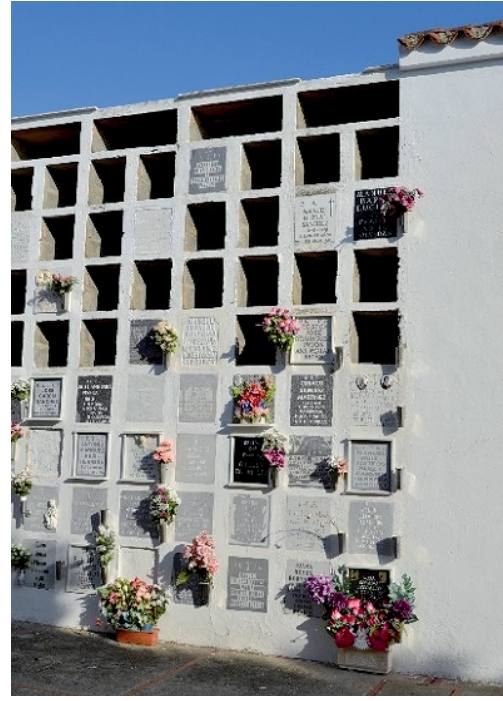

Figura 4. Columbario en el cementerio de Rota. Fuente: propia. prácticamente una condena infernal si se hace sobre la tumba de un niño, en la que se escribía esta advertencia en latín SG.GA -sacrilegio grave(Dominicus, 1785: 151 y 363); si bien desde la antigüedad existen muchos epígrafes que insinúan lo que puede pasar si aquello se toca con mala fe (Hoyo, 2014: 809-824). Es una evidencia el que, en los rituales de pérdida absoluta de cenizas, no puede existir la idea de profanación.

Con esta idea conservadora nacen los nuevos cementerios intramuros de la ciudad, o, mejor dicho, se recuperan las criptas parroquiales, prohibidas por Carlos III, para convertirse en columbarios. Pequeños camposantos de poca capacidad, pues elegir descansar en una determinada iglesia se debe a las devociones particulares que pueda haber en ese templo (cofradía a la que se pertenece, lugar en donde el fiel fue bautizado, hizo su primera comunión, contrajo matrimonio, la iglesia está al lado de su casa, peregrinaba con asiduidad...). La cuestión de la memoria es aún más profunda, al igual que en los camposantos y, siguiendo las costumbres de nichos y panteones, los columbarios se compran en vida y se rotulan con el nombre de la familia que un día los ocuparán, conociéndose muchos de sus vecinos que han tenido en vida similares devociones.

Vamos a poner el ejemplo del columbario de la antigua Trinidad Calzada de Úbeda. Este considerable templo, coadjutor de la parroquia de San Nicolás de Bari, contaba con una amplia cripta abandonada desde la exclaustración y 

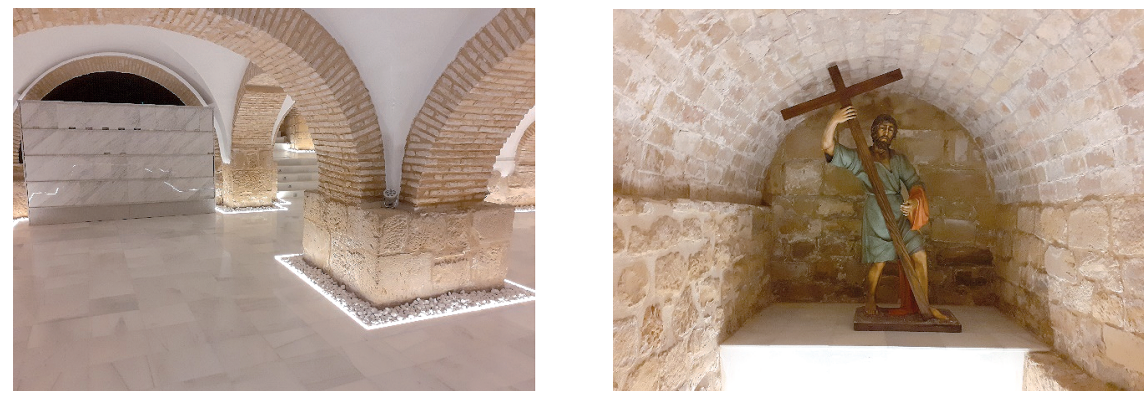

Figuras 5 y 6. Columbario de la Trinidad Calzada de Úbeda y capilla del Cirineo en el mismo. Fuente: propia.

que había servido como un abandonado trastero. En 2019 recupera el fin para el que había sido construida en el Barroco, convirtiéndose en el primer columbario intramuros de la ciudad, y con un llamativo reclamo para los fieles de las cinco cofradías de pasión establecidas canónicamente en dicha parroquia. Al presente cuenta con dos estructuras de mármol de cuatro pisos, con doce espacios para una urna en cada piso, por lo que la capacidad actual es para 96 difuntos. En este sentido, se ha diseñado un espacio diáfano, muy agradable, en donde no se palpa la muerte, sólo pequeñas plaquitas plateadas indican el nombre del finado.

En segundo lugar, los columbarios de los templos permiten la creación de capillas con la función de colocar imágenes al culto o lienzos; en este caso se ha creado la capilla del Cirineo. Por último, existe la posibilidad de cultos, pues en un columbario, al igual que en una cripta, se puede oficiar la Eucaristía, bien con un altar móvil o creando un presbiterio con la misma disposición que existía en las grandes criptas de inhumación. Importantes ejemplos son el panteón de reyes de San Lorenzo de El Escorial o el panteón de los duques de Osuna en la colegiata de la mencionada ciudad, que incluso desarrolla una pequeña sillería coral hispánica.

Si bien, todos los columbarios intramuros no están apareciendo en iglesias, hay lugares más peculiares, como aquellos que se ubican en las casas de hermandad. Se trata de un nuevo espacio que está surgiendo de esta nueva tipología arquitectónica, generalmente realizada por hermandades de pasión; en el lugar donde tienen sus dependencias para guardar sus tronos, sus piezas de orfebrería y sus archivos. Suelen contar con un salón de actos para celebrar asambleas y charlas formativas, una sala de reuniones para la junta directiva, a veces una sala de ocio para los miembros de la banda musical, en donde puede haber futbolines, una pequeña barra con bebidas espiritosas... Y, final- 
mente, como nueva estancia ubicada en el sótano, el columbario para los hermanos fallecidos. Los ejemplos más llamativos están surgiendo en la ciudad de Málaga, caso de la hermandad del Rocío, el Sepulcro - muy curioso, pues presenta un presbiterio con una dolorosa de vestir-, Nueva Esperanza -en el mismo se venera la imagen primigenia de la hermandad-, etc. Dentro de la tipología de estos columbarios, quizás uno de los más llamativos sea el de la Santa Vera Cruz de Alhaurín el Grande, pues el testero del columbario es el presbiterio y, en el centro de éste, se abre un nicho horizontal en donde se venera un Cristo yacente.

Tanto las reconversiones de las criptas como los sótanos de las casas de hermandad están devolviendo los difuntos intramuros de la ciudad, si bien con una presencia muy desapercibida. La muerte no existe en la ciudad, para ir a los columbarios primero hay que saber de su existencia, pues son lugares íntimos y, de acceder, difícilmente - por su forma- nos sentiremos incómodos.

Una nueva tipología muy reciente está creando nuevos edificios adaptados exclusivamente para este fin, que, de hecho, están conformando nuevos cementerios de importante tamaño. Un ejemplo puede ser el gran columbario de Jerez de la Frontera en las antiguas bodegas Bobadilla, que se proyectó en 2009 para un número inicial de 27.000 urnas. No obstante, la concepción de macro columbario todavía no ha calado bien en la sociedad.

La posibilidad de transportar las cenizas a cualquier lugar, siempre y cuando se quieran conservar, ha hecho posible la existencia de localizaciones de descanso «friki» individualizadas. Pongamos algunos ejemplos llamativos: Orson Welles está en un brocal de pozo ciego de la finca de los Ordoñez en Ronda; las cenizas de Frida Kahlo descansan en una urna de barro con extremidades de sapo que adorna un tocador de la casa azul.

Hay veces en que parte de las cenizas se quieren conservar de formas muy personales, a veces un tanto inverosímiles, caso de los colgantes, las joyas en donde se construye una piedra preciosa con el carbono de las cenizas, la mezcla de éstas en la cerámica para crear un adorno compacto, la disolución en el óleo para para que queden adheridas en un lienzo, normalmente sobre el que se pinta un retrato del difunto...

Hasta aquí los casos en donde las cenizas se han conservado, nos quedaría la última tipología afín a los camposantos, los espacios diseñados dentro de ellos para que las cenizas no sean conservadas. Áreas pensadas para devolver al difunto a la colectividad dentro de un recinto generalmente sagrado.

La lógica sería comenzar por los campos de urnas, con la práctica de la inhumación. Las más conservadoras colocan una pequeña lápida sobre el suelo, indicando el lugar, si bien, lo más común es que se busque el anonima- 
to mediante la inhumación en urnas biodegradables. Generalmente es una suerte de jardín botánico de especies muy precisas y de un alto contenido iconológico a lo largo de la historia, así las cenizas se unirán al humus de un olivo, algarrobo, pino, abeto... o de arbustos aromáticos como el romero, tomillo...

Dentro de todos los árboles, el más común de encontrar en estos nuevos camposantos es el olivo, por muy diversas circunstancias que van más allá de su longevidad milenaria. Lo más importante que pretende un ser humano a lo largo de su vida -sea de la religión que sea- es alcanzar la paz; por ello se desea que descanse en paz, y el acebuche es el árbol de la paz. La mitología griega así lo estableció cuando Atenea ganó el patronazgo de la ciudad de Atenas a Poseidón, regalándole este precioso árbol que daba fruto, madera y aceite en períodos de paz; pero que no daba cosecha si iban a la guerra con el caballo que les había regalado el dios del mar -así lo reflejó Fidias en el Partenón-. Con su preciado zumo fueron ungidos los reyes desde la antigüedad -en el Antiguo Testamento el profeta Samuel ungió a David de niño (I Samuel, 16, 113)-. Con sus ramas fue aclamado Cristo cuando entró triunfal en Jerusalén, cuando traía la paz, y bajo el mismo árbol sudó sangre antes de enfrentarse a su Pasión (Lc 22, 44). Sin entrar en otras religiones, con su preciado aceite en la católica se unge a los que van a ser bautizados, a los que recibirán al Espíritu Santo por el sacramento de la Confirmación, a los que serán ordenados sacerdotes, a los que serán exorcizados y a los ungidos para abandonar este mundo con los tres santos óleos, que se consagran y bendicen por los obispos en las catedrales en la mañana del Jueves Santo: el Crisma que es el que se consagra (el obispo sopla sobre él) y se bendicen el Catecúmenos y el Enfermos.

Todas estas ideas en el fondo conllevan a que el olivo sea el árbol ideal para que descansen las cenizas, para que vuelvan a la intangibilidad y sólo una plaquita entre muchas, a la entrada de estos bosques, diga que las cenizas fueron allí inhumadas, pero que el difunto es abstracto, difuso. Así, quizás no haya muerto, pues - dejando de lado cualquier religión- si se ha unido a un árbol, podemos pensar en una metamorfosis o nuestra mente es capaz de asociar una nueva vida diferente, más corporal que espiritual e incluso tangible. Por ello se está incorporando a las cenizas una semilla para que veamos brotar el árbol como la nueva vida. Una película dramática donde esta idea queda muy clara es La huérfana (Colletserra, 2009), en donde la madre adoptiva de la «niña» tiene en un tiesto una planta florida nacida de las cenizas de su bebé, muerto en el parto.

La metamorfosis del ser humano en un vegetal es un imposible, pero aceptado por la sociedad desde la antigüedad. Así Dafne se transforma en lau- 

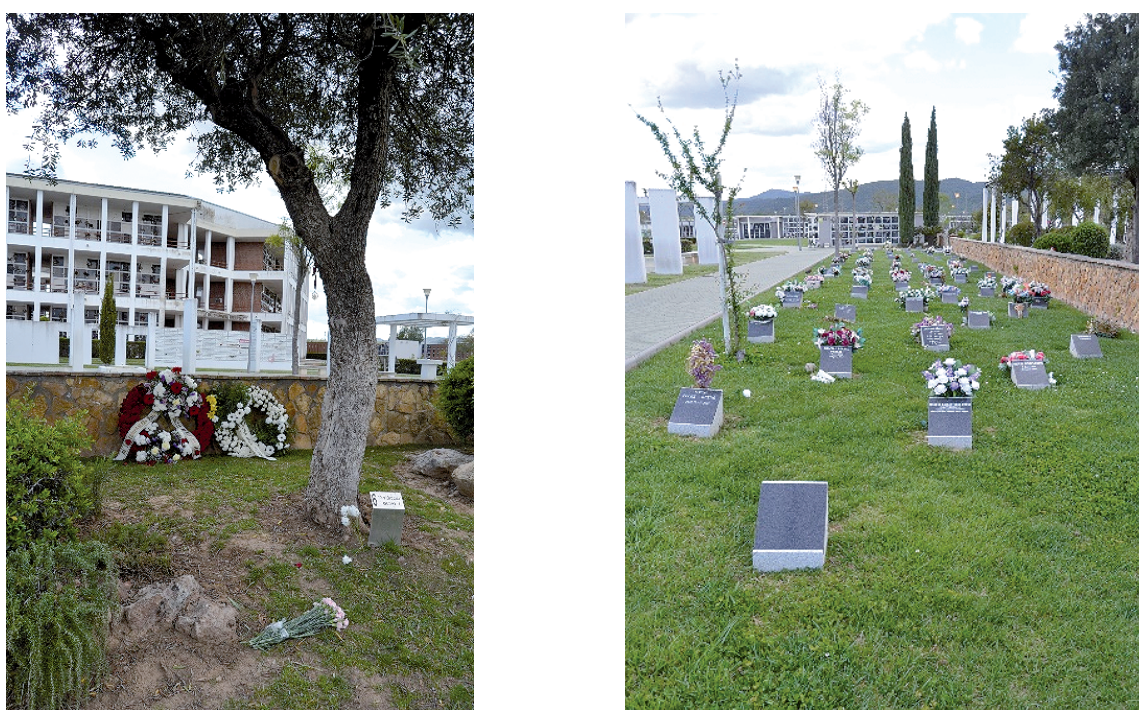

Figuras 7 y 8 . Bosque de inhumación de cenizas alrededor de plantas y zona de inhumación de cenizas con lápida en el cementerio de la Fuensanta de Córdoba. Fuente: propia.

rel cuando iba a ser alcanzada por Apolo (Ovidio, 27-29); escena perfectamente representada por Bernini -galería Borghese-. Incluso es muerte aceptada hasta en los dibujos animados. Conmovedora fue la metamorfosis de los gnomos David y Lisa a los 400 años en cerezos al llegar a las montañas del más allá (BRB Internacional, 1985). También, la transformación en estrellas. Una de las conversaciones más curiosas la tenemos en la versión de Disney del Rey León (Minkonff, 1994), cuando Simba, Timón y Pumba discuten sobre qué son las estrellas. Curiosamente Pumba da la versión correcta, indicando que es gas ardiendo a gran distancia, a lo que Simba le responde que, para él, como buen cerdo, todo es gas; y seguidamente viene la respuesta de Simba, pensando en su fallecido padre, diciendo que todos los reyes que han muerto están en el cielo observando en forma de estrella. Con posterioridad es el alma de Mufasa la que se le aparece a Simba en forma de constelación.

Una forma colectiva de descanso de cenizas son los ceniceros. Se trata de una especie de cavidad en donde se vierten cenizas de cualquier persona y, en una pared colindante, se escribe su nombre en una placa. Indudablemente el espacio aglomerado de ínfimas placas, las unas con las otras, rompe toda la idea de los altarcitos creados en las repisas de los nichos o sobre las lápidas, o incluso tierra en donde se trasladan objetos del hogar para decorar la necrópolis (Jordán \& Jordán, 2019: 134-135). 
En el fondo, no deja de ser un agrado al difunto, no sólo con flores; sino juguetes si se trata de un niño, fotos, velas, santos a los que le tenía devoción, penitentes de barro con la túnica de la cofradía a la que pertenecía... A veces se puede llegar a una exageración de una profusa decoración del camposanto, como es costumbre en México para la fiesta de Todos los Santos -1 de noviembre, en que se celebra la Iglesia Triunfante- y de los Fieles Difuntos -2 de noviembre, en que se conmemora la Iglesia Purgante-. Un ejemplo muy simpático lo tenemos en una de las películas de animación más dulce y tierna que haya realizado la factoría de Disney, como es Coco (Unkrick \& Molina, 2017); desarrollándose gran parte de la trama del pequeño Miguel en estas jornadas en el decorado camposanto de su pueblo. Es un axioma que muy existente está la muerte en esa película, distante absoluta de las plaquitas que se vienen poniendo en estos jardines de la memoria, donde ya no está el difunto y, por lo tanto, no se le puede venerar físicamente.

Volviendo a los ceniceros, suelen ser artísticos, con formas singulares; como pequeñas pirámides (cementerio de San José de Almería, Montjuic...), con gramática de pebetero (mancomunado de Cádiz), etc. De todos ellos queremos destacar el gaditano, por encontrarse dentro de la recreación de la cella de un templo griego -en este sentido, emulando una religión inexistente al presente-, con relieves dedicados a Proserpina y un recuerdo a la metamorfosis con la expresión de Ovidio omnia mutantur, nibil interit (todo se transforma, nada perece). Concretamente, dos bajorrelieves narran dos momentos del mito. El primero se basa en la pérdida, mientras Proserpina se dispone a comer las granadas del infierno que la convertirán en la esposa de su tío Plutón -dios del inframundo y de los muertos-; Ceres -su madre, diosa de la agricultura- la busca desesperada, enfadándose de la argucia realizada por su hermano. Triste, se niega a cuidar de los campos, llegando el invierno perpetuo. Ante esta situación, Júpiter -dios del cielo- convence a sus dos hermanos de que la sobrina esté medio año con su marido y el otro con su madre. El segundo relieve muestra la llegada de la primavera, el encuentro entre madre e hija, la alegría, el abrazo futuro que, de alguna manera, tendremos con los seres que han dejado este mundo, siguiendo el mismo camino que en el que ellos nos precedieron.

En otras ocasiones, es la misma agua que emana por el camposanto la que deposita las cenizas en la tierra; caso del mirador del agua del cementerio de San José de Granada, con un pebetero decorado con una alfa y una omega indicando el principio y fin de todas las cosas. Debajo, un jardín pedregoso, en donde el agua no se convierte en barro y cercado con testeros pensados para poner placas con nombres. En realidad, otro nuevo espacio en los camposantos en donde la mente nos dice que hay difuntos, pero estos no son tangibles. 
Quizás, vienen a acrecentar la idea clásica, ya existente en la inhumación, de que el alma del difunto no habita en el cementerio, sino que allí sólo están sus reliquias para que lo recordemos. Esta idea ha sido llevada al cine de una manera muy efectiva por Burr Steers en Más allá del cielo (Steers, 2010), cuando Charlie St. Cloud pierde a su hermano pequeño (Sam) en un accidente de coche mientras él conducía. El cargo de conciencia le hace ir a vivir al cementerio donde descansa su hermano, convirtiéndose en celador del mismo, si bien nunca el espíritu de Sam se aparece junto a su tumba, sino en el bosque cercano al camposanto.

Todos estos nuevos espacios en realidad están cambiando la visión del camposanto, en la mayoría de los casos anexos al cementerio romántico. Efectivamente son áreas más amplias, más botánicas que urbanas, pero con un menor crecimiento. Es una lógica, el camposanto extramuros crecía por la llegada de nuevos habitantes, que ocupaban un espacio; las cenizas, cuando no se pretenden conservar, reducen ese espacio. El cementerio se convierte en un contenedor infinito que, si crece, es por la anexión de una nueva forma de deposición de éstas que un determinado cementerio ofrezca y que, en muchas ocasiones, hace a cada necrópolis exclusiva, pues no es lo mismo un lago, un canal, un bosque de olivos o una plantación de arbustos aromáticos.

\section{LA ACEPTACIÓN CONTEMPORÁNEA DE LA CREMACIÓN}

Por último, tendríamos que plantear si estas nuevas formas tanto de incineración, como de deposición de cenizas están siendo aceptadas por la sociedad contemporánea, y debemos de partir de que efectivamente la cremación se ha aceptado como el principal rito funerario que existirá en el futuro. Los medios de comunicación, sobre todo en grandes obras cinematográficas de ciencia ficción, basadas en mundos paralelos, inciden en esta cuestión. Por ejemplo, Anakin Skywalker (Darth Vader) es cremado por su hijo Luke en el Retorno del Jedi (1983), mucho antes de que cintas posteriores nos lo muestren como un niño. Avatar (2009) comienza con la incineración del hermano de Jake Sully. De entre todos, quizás el caso más duro sea el de La materia oscura (2019), basada en la trilogía de Philip Pullman. En el universo paralelo el niño giptano Billy Costa muere al ser separado de su daimonion y es incinerado en una pira. Aún mayor dureza, por tratarse de un asesinato, lo encontramos en la sociedad futura superpoblada que plantea Tommy Wirkola en Siete hermanas (2017), cuando engañan a una niña, que va a ser dormida y congelada en una cápsula, para ser despertada en un futuro con menos población; en realidad, una vez anestesiada, el aparato la incinera en vida. 

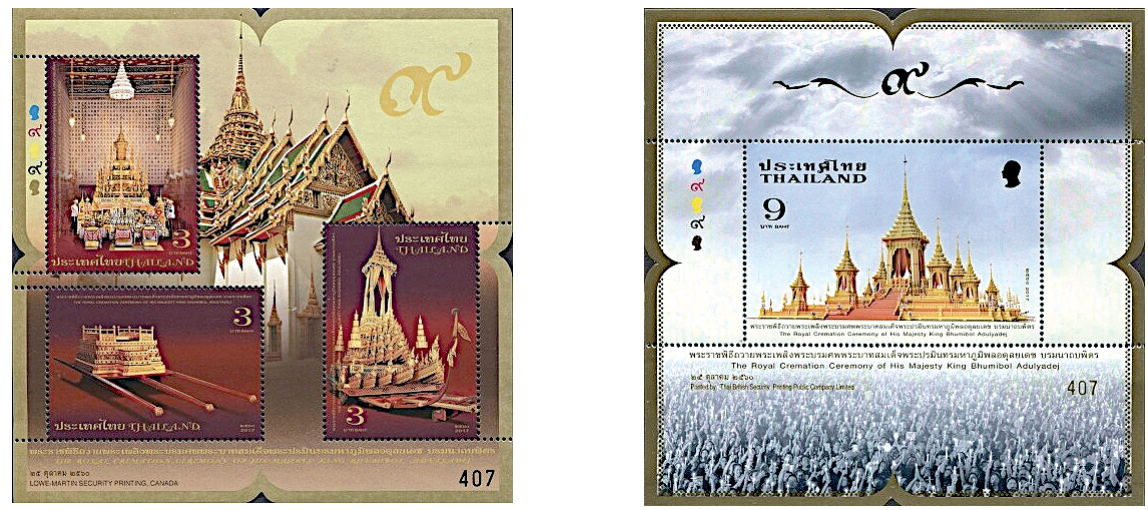

Figuras 9 y 10. Sellos oficiales de la capilla ardiente, carrozas fúnebres y crematorio real editados por Tailandia para conmemorar la cremación de Rama IX.

Creemos que sería conveniente plantear la incineración en la mentalidad de las altas jerarquías y, en este menester, debemos de empezar por las monarquías. Lógicamente los reyes de religión hinduista o budista tienen en sus culturas estos ritos, aunque difieren. En el caso de los hinduistas -ejemplo de Nepal- se lleva a cabo una cremación muy rápida del monarca en una pira a orillas del río Bagmati, comenzando el fuego por una antorcha que se pone sobre la cara descubierta del difunto. Terminada la cremación, las cenizas son depositadas en el río. El último caso fue con Birendra (1972-2001), fallecido en el famoso regicidio de 2001. Perdida la costumbre en la realeza tras la defenestración de Gyanendra (último rey de Nepal, 2001-2008) y convertirse el país en una república.

Mucho más complejo es el caso budista, llegando a la máxima expresión en Tailandia, en donde la incineración del rey se produce aproximadamente un año después de su muerte, permaneciendo en el Kot, ${ }^{10}$ hasta que éste es trasladado en una suntuosa carroza desde el salón de trono del palacio hasta el crematorio real, edificio efímero construido sólo para una incineración. Tras complejísimos rituales de muchas horas, el rey es cremado dentro de su Kot. El último caso ha sido el de Rama IX (1946-2016). Con una ostentación parecida encontramos los ejemplos de Laos, caso de Sisavang Vong (19461959) -al presente el país es una república-, Camboya con Norodom Sihanouk (1993-2004) y, en menor medida, en Bután, siendo el último ejemplo el de Jidme Dorji Wangchuck (1952-1972). En los casos budistas, las

10 Urna muy artística en donde el cadáver rey es introducido en posición de meditación. 
cenizas sí se suelen guardar y el funeral es algo tan importante que se emiten sellos postales para la ocasión, ejemplos tenemos en Laos o los más recientes en Tailandia, en donde se hicieron 2 minisheet, uno con tres sellos, dedicados a la carroza funeraria y al Kot expuesto en el palacio real. El segundo plasma el crematorio real junto a una silueta numismática del Rama IX.

A estos casos asiáticos hay que añadir el del Mikado. Si bien es cierto que en Japón existen casos en los que el Tenno ha sido cremado, en los últimos siglos se han realizado ceremonias fastuosas de inhumación. Aún, así, en una idea de modernidad y humildad, el emperador Akihito (1989-2019) expresó su deseo de ser incinerado, aún no se sabe si se llevará a cabo y si, de cumplirse la voluntad, Naruhito (2019-hasta el presente) seguirá la costumbre.

Respecto a los reyes europeos, es algo muy extraño, pues no hay ejemplos más allá del caso danés de Enrique de Laborde de Monpezat, ${ }^{11}$ cumpliéndose su voluntad, pero no siendo bien aceptada por la reina Margarita II. También, hay algunos ejemplos en infantes, como el de Pilar de Borbón (1936-2020), quien, además, decidió que sus cenizas fueran enterradas en el cementerio de San Isidro de Madrid, renunciando a su derecho en el panteón de infantes del monasterio de San Lorenzo de El Escorial.

En la alta nobleza europea es igual de extraño, pues mantienen sus panteones. El ejemplo más llamativo y chocante de cremación es el de la duquesa de Alba; Cayetana Fitz-James Stuart, fallecida en 2014, declinando el panteón de Loeches frente a un nicho en el santuario sevillano de los gitanos, convirtiéndose en un atractivo más del templo en donde se venera al Nazareno de la Salud. No obstante, tanto los funerales en la catedral metropolitana de Sevilla como la forma del nicho llevan de manera explícita la idea de conservación de la reliquia, que ya comentábamos en las primeras incineraciones del cementerio de Milán.

A nivel de las altas jerarquías católicas es muchísimo más extraño, sólo hay que pensar que la tumba de un obispo o un arzobispo siempre mejora la historia y la grandeza de una catedral. No es lo mismo un templo episcopal con muchas tumbas de sus obispos (caso de Cuenca, Zamora, Salamanca...) frente a nuevas catedrales que, a pesar de tener los privilegios de pontificales, no tienen en su sagrado suelo aún tumbas de obispos (Huelva, Getafe, Terrassa...). $\mathrm{Si}$ a esto añadimos la importancia de que un cardenal -sea o no diocesanodecida, por su privilegio de Príncipe de la Iglesia, enterrarse en una determinada catedral, el empaque de la misma es mucho más importante.

11 Príncipe consorte de Dinamarca desde 1972 hasta 2016 como esposo de Margarita II de Dinamarca. 
En este sentido, la cremación de un obispo es algo muy extraño; aun así, hay algunos ejemplos como el de Michael Evans (obispo de East Anglia, 2003-2011). No obstante, no perdiéndose su presencia, pues las cenizas fueron enterradas en la catedral de San Juan Bautista de Norwich (ciudad principal de la diócesis de East Anglia). Más extraño es el caso de Jaume Camprodón Rovira (obispo de Gerona, 1973-2001) que, pese a tener derecho de inhumación en la catedral de Gerona, optó por donar su cuerpo a la ciencia y su posterior incineración. Es uno de los pocos casos en los que se puede decir que se ha perdido la memoria del prelado, al igual que veíamos en todos los supuestos de esparcimiento de cenizas que hemos tratado en los camposantos.

\section{CONCLUSIÓN}

Debemos de indicar que en los demás niveles no hay distinciones, se respetan las decisiones de quienes quieren ser inhumados y quienes incinerados; aunque es cierto que la sepultura cada vez es más afín a personas de mayor edad y la incineración entra con fuerza en las nuevas generaciones. Quizás, es la conclusión a la que queremos llegar con este trabajo. La cremación y posterior pérdida de las cenizas conlleva a esconder la muerte en un mundo en el que pretendemos ser felices y donde ésta no tiene cabida. Se está implantando vivir en una sociedad de suma belleza, en donde se intenta basar la búsqueda de la felicidad con un consumo materialista y se niega cualquier clase de metafísica como algo del pasado, no asumible por la ciencia empírica.

En esta sociedad no se puede aceptar el sufrimiento, el dolor y, mucho menos, la muerte. Por lo tanto, hay que negarla, que viene a ser lo mismo que tapar el sol con un dedo. Hay que intentar expresar por todos los medios que la muerte no existe. Quizás, por esta circunstancia, fue tan premiada la película Un monstruo viene a verme, pues Juan Antonio Bayona mostró con gran maestría a la sociedad feliz - pero que con facilidad se derrumba- que la muerte sí existe y que puede ser "más que dura» - palabras finales que el monstruo le dice al joven Conor O’Malley- (Bayona, 2016). En resumen, el negar la muerte no deja de ser vivir en una falacia, ¿es bueno, es positivo el creerse esta invención? Será el futuro el que nos conteste. 


\section{BIBLIOGRAFÍA}

AAVV. (1998). La Sagrada Biblia. Madrid: Ediciones San Pablo.

AAVV. (2001). Los Papas, veinte siglos de Historia. Ciudad del Vaticano: Administración de la Patriarcal Basílica de San Pablo.

AAVV. (2016). Misal Romano. Madrid: Edición de la Conferencia Episcopal Española.

AAVV. (2018). Ritual de Exequias. Madrid: Edición de la Conferencia Episcopal Española.

Alcalá Moreno, I. (1992). La religiosidad popular ante la muerte. Testamentos de Jódar, siglos XVI al XVIII. Sumuntán, 2, 23-29.

Aldobrandini, I. -Clemente VIII- (1595). Pontificalem Romanum. Roma: Santa Sede.

Amado Lorenzo, A. (2012). Tumba de tumbas. Los concursos de Le Fosse Ardeatine y el Tanatorio de León. XIV Congreso internacional de expresión gráfica arquitectónica. Oporto, 293-296.

Barroso Torres, J., Alcalá Moreno, I. \& Barroso Navarro, J. (2017). El lenguaje de las campanas en la ciudad de Jódar (Jaén). Sumuntán, 35, 283-302.

Díaz Díaz, T. (2014). Evolución del retrato funerario: la necesidad de perpetuidad. El mundo de los difuntos: cultos, cofradías y tradiciones. San Lorenzo de El Escorial, 623-640.

Dominicus, J. (1785). Notae et Siglae quaeu in nummis et lapidibus apud Romanos obtinebant. Venecia.

Fischer, N. (2019). La cultura europea de los cementerios: pasado y presente. Revista murciana de antropología, 26, 17-32.

García Lorca, F. (1997). La casa de Bernarda Alba. Barcelona: Espasa.

Garrido Jiménez, M. (2014). Columbarios y urnas funerarias. El mundo de los difuntos: cultos, cofradias y tradiciones. San Lorenzo de El Escorial, 911-922.

Gómez Navarro, S. (2014). La diferencia entre el desamparo y el consuelo: una reflexión sobre la muerte en el protestantismo y en el catolicismo. El mundo de los difuntos, cultos, cofradias y tradiciones. San Lorenzo de El Escorial, 9-20.

Grimm, J. \& W. (2013). Cuentos de los hermanos Grimm. San José de Costa Rica: Imprenta Nacional.

Hoyo Calleja, J. del (2014). Ne velis violare. Imprecaciones contra los profanadores de tumbas. El mundo de los difuntos: cultos, cofradías y tradiciones. San Lorenzo de El Escorial, 809-824. 
Jordán Montes, J.F. \& Jordán de la Peña, A. (2019). En el limes: los no cementerios; en el limbo: los no duelos. Bebés, suicidas y accidentados con muerte en la mentalidad tradicional rural española. Revista Murciana de Antropología, 26, 111-172.

Linage Conde, A. (2014). Agonía, muerte y posteridad en Sepúlveda. El mundo de los difuntos: cultos, cofradías y tradiciones. San Lorenzo de El Escorial, 147-166.

Lorite Cruz, P. J. (2012). La figura de Cristo Yacente, ¿muerte o sacramentación. Claseshistoria, 274, 1-11.

Lorite Cruz, P. J. (2014). Las exequias de niños en el catolicismo, fiesta "alegre" a nivel iconográfico dentro de la muerte. XXII Simposium del Instituto Escurialense de Investigaciones Históricas y artísticas. "El mundo de los difuntos: culto, cofradías y tradiciones." San Lorenzo de El Escorial, 229-246.

Lorite Cruz, P. J. (2017). Las iconografías fundamentales de la semana santa. Religiosidad popular: cofradias de Penitencia. San Lorenzo de El Escorial, 847-864.

Marra, Ch. (2016). Le origini e gli sviluppi della cremazione in Europa. Universidad de Bolonia: Tesis doctoral.

Martínez Vicente, M. (2019). Una mirada al futuro próximo en la transformación de los cementerios desde la perspectiva de la arquitectura emocional. Revista Murciana de Antropología, 26, 95-110.

Ovidio (1995). Las metamorfosis. Barcelona: Edicomunicación.

Pardo, A. (2007). Oracional. Madrid: Biblioteca de Autores Cristianos.

Pérez Ortega, M. U. (2009). Costumbristas giennenses. Estudio y antología. Jaén: Instituto de Estudios Giennenses.

Rodríguez Becerra, S. (2007). Rituales de muerte en Andalucía. Significados y funciones. La función simbólica de los ritos. Almería, 129-157.

Sánchez Noriega, J. L. (2010). Historia del cine. Teoría y géneros cinematográficos, fotografía y televisión. Madrid: Alianza.

Schriewer, K. \& Martínez Cavero, P. (2012). Reflexiones antropológicas sobre la historia y la actualidad del cementerio en Europa. Revista Murciana de Antropología, 19, 9-26.

Suetonio (2000). Los doce césares. Barcelona: Iberia.

Ratti, A. -Pius XI- (1925). Ritualem Romanum. Ciudad del Vaticano.

Ripa, C. (2002). Iconología. Madrid: Ediciones Akal.

Triviño Monrabal, Sor M.V. (2014). La muerte blanca. El mundo de los difuntos: cultos, cofradías y tradiciones. San Lorenzo de El Escorial, 659-680. 


\section{FILMOGRAFÍA}

Ariza, F. (2019). Ay mi madre. España.

Bayona, J. A. (2016). Un monstruo viene a verme. España y EUA.

BRB Internacional (1985). David el gnomo (serie). España.

Borg, L. (2019). La materia oscura (serie). Reino Unido.

Cameron, J. (2009). Avatar. EUA.

Colletserra, J. (2009). La huérfana. Francia, Alemania, EUA y Canadá.

Espinosa, A. (2011). Pulseras rojas (serie). España.

Globomedia. (1995). Médico de familia (serie). España.

Groening, M. \& Brooks, J. L. (1989). Los Simpsom (serie). EUA.

Marquand, R. (1983). El Retorno del Jedi. EUA.

Mercero, A. (1981). Verano azul (serie). España.

Minkonff, R. (1994). El rey león. Factoría de Disney. EUA.

Moreno, J. L. (2003). Aquí ni hay quien viva (serie). España.

Steers, B. (2010). Más allá del cielo. EUA.

Unkrick, L. \& Molina, A. (2017). Coco. Factoría de Disney. EUA.

Wirkola, T. (2017). Siete hermanas. Reino Unido.

\section{WEBGRAFÍA}

https://www.cemabasa.com (Página oficial del cementerio mancomunado de Cádiz).

https://www.cbsa.cat (Página oficial de cementerios de Barcelona).

https://www.louvre.fr (Página oficial del Museo del Louvre).

https://www.museeorsay.fr (Página oficial del Museo de Orsay de París).

https://www.museojulioromero.cordoba.es (Página oficial del Museo Julio Romero de Torres de Córdoba). 
